wać można umieszczenie w opracowanej według klucza alfabetycznego bibliografii Mistrza Wincentego tzw. Kadłubka po Stanisławie ze Skalbmierza (s. 197). Zaskakuje ponadto stosunkowo mały udział opracowań francuskojęzycznych w obszernej bibliografii. Uwagi powyższe mają jednak charakter „kronikarski” i w niczym nie umniejszaja wartości książki. Czytelnik otrzymuje bowiem w pracy A. Fijałkowskiego cenna i wartościowa analizę średniowiecznej myśli pedagogicznej.

\section{Krzysztof Ratajczak}

${ }^{1}$ Np: A. Fijałkowski, Wychowanie kobiet $w$ sivietle pism Wincentego z Beauvais († 1264), w: Partnerka, matka, opiekunka. Status kobiety w starozytności $i$ średniowieczu, red. J. Jundziłł, Bydgoszcz 1999, s. 282 -296; tenże, Wincenty z Beauvais (ok. I194-1264) w Royamount - dominikanin wśród cystersów, w: Cystersi w spoleczenistwie Europy Srodkowej. Materiaty z konferencji naukowej odbytej w klasztorze oo. Cystersów w Krakowie Mogile z okazji 900 rocznicy powstania Zakonu Ojców Cystersów. Poznań-Kraków-Mogila 5 - 10 października 1998, red. A. M. Wyrwa, J. Dobosz, Poznań 2000, s. $782-798$.

2 Uzasadnienie kar cielesnych $w$ średniowieczu, w: Źródla do historii wychowania (Wybór), Wybrał i objaśnił S. Kot, cz. I, Warszawa 1929, s. 119-122 oraz pod tym samym tytułem w: Źródla do dziejów wychowania i myśli pedagogicznej, t. 1: Od wychowania pierwotnego do korica XVIII stulecia, wybór i opracowanie S. Wołoszyn, wyd. II zmienione, Kielce 1995, s. 160-164.

A. Fijałkowski, Puer eruditus. Idee edukacyjne Wincentego z Beauvais (ok. 1194-1264), Warszawa 2001 , s. 64 i nn.

4 Tamże, s. 90.

\title{
Historia, społeczeństwo, wychowanie. Księga pamiątkowa dedy- kowana Profesorowi Józefowi Miąso, pod red. K. Bartnickiej, Pultusk - Warszawa 2004, ss. 548
}

Wyższa Szkoła Humanistyczna im. Aleksandara Gieysztora w Pułtusku oraz Instytut Historii Nauki Polskiej Akademii Nauk wydały w 2004 roku pracę Historia, spoteczeństwo, wychowanie. Została ona zadedykowana Profesorowi Józefowi Miąso, jednej z najbardziej zasłużonych postaci w polskiej historii wychowania. Do jej powstania przyczynili się nieomal wszyscy najważniejsi badacze tej dyscypliny.

Prezentowana pracę otwiera artykuł Kaliny Bartnickiej zatytułowany Profesor Józef Miaso - historyk wychowania, oświaty, nauki. Uczony, mistrz, przyjaciel $i$ kolega. Ukazuje on sylwetkę Jubilata i jego dość skomplikowana drogę edukacyjna, bo jak napisał on sam o sobie: Poczynajac od 6 roku zycia, chodzilem do dwóch szkót podstawowych, jednej doksztalcajacej $i$ trzech szkót średnich. Studiowatem $w$ dwóch uniwersytetach, miatem dwóch mistrzów naukowych, których inspiracjom intelektualnym i zwyklej ludzkiej zyczliwości zawdzięczam bardzo wiele ${ }^{1}$. K. Bartnickiej ponadto udało się przedstawić Józefa Miąso jako niezwykłego człowieka, bo Jego biografia jest $i$ wyjatkowa $i$ typowa zarazem, jak wiele życiorysów Polaków tego pokolenia, którym los przynosit wielkie zagrozienia ale także wielkie zyciowe szanse ${ }^{2}$. Część wstępna, ,jubileuszowa", pracy uzupetnia Bibliografia prac Józefa Miaso za lata 1958-2003, która pracowicie zestawiła Ewelina Tylińska.

Praca składa się z czterech części. Pierwsza z nich nosi tytuł Tradycja uniwersytecka i składa się nań dziesięć artykułów. Autorką pierwszego (Upadek uniwersytetów we Francji w XVIII w.) jest K. Bartnicka. Przedstawia ona tradycję, sięgająca nieomal sześciuset lat, kształcenia uniwersyteckiego we Francji i wskazuje na główne przyczyny jej upadku: rozdźwięk między programami nauczania (anachronicznymi i nieużytecznymi) a potrzebami społeczeństwa, niechęć do uniwersytetów niektórych środowisk (np.: ówczesnych filozofów, chociażby D. Diderota), wiązanie tychże instytucji z feudalnym porządkiem społecznym. Były to przyczyny na tyle głębokie, jak dowodzi K. Bartnicka, ze Francuzi zechcieli wskrzesić idee uniwersyteckie dopiero po stu latach (1893 r.).

Kolejnym autorem omawianego tomu jest krakowski badacz, Julian Dybiec. Jego artykut dotyczy współpracy między uniwersytetami od czasów średniowiecznych do najnowszych (XX 
wiek). Autor ten ukazuje jak wyglądała owa współpraca dawniej i co ja najmocniej pobudzało (np.: spory religijne). Postuluje też, aby współczesne uniwersytety stały się swiattem dla ludzkości na bezdrozach przetomu cywilizacji ${ }^{3}$. Współczesna wersja, opisywanej przez J. Dybca, współpracy winna doprowadzić do wypracowania nowej idei uniwersytetu wspótczesności $i$ przyszlosici ${ }^{4}$.

Kolejna autorka, Danuta Drynda, pisze o kontrowersjach wokół projektów i ustaw o szkolnictwie akademickim w Drugiej Rzeczypospolitej (1918 - 1939). Inspiracja do napisania tego artykułu było oczekiwanie autorki na nową ustawę o szkolnictwie wyższym w Polsce, liczne krytyczne poglądy na temat polskiego wspólczesnego życia akademickiego. Intencją D. Dryndy jest więc pokazanie, że temu zagadnieniu „od zawsze" takie kontrowersje towarzyszyły.

Działalność Uniwersytetu im. Jana Kazimierza we Lwowie w czasach II wojny światowej przedstawia z kolei Jan Draus. Szczególna uwagę tego autora przykuwa praca konspiracyjna tej uczelni. Ogromne braki źródłowe J. Draus zdołał odtworzyć $w$ relacjach zebranych przezeń w latach siedemdziesiątych od żyjących wówczas jeszcze profesorów lwowskich, animatorów tajnego nauczania uniwersyteckiego we Lwowie.

Kierunki rozwoju uniwersytetów europejskich w XVIII wieku przedstawia Janina Kamińska. Obszernie opisuje ona wszystkie centra akademickie w Europie, zainteresowania ich badaczy, popularyzowane przezeń idee i zagadnienia społeczno-gospodarcze. Wskazuje jednocześnie, jaki ideał uczelni wypracowała osiemnastowieczna Europa: instytucji, która kształtowała obywateli przydatnych państwu.

Kolejny artykul tomu to Uniwersytet Szczecinski i jego tworzenie $w$ interpretacji prasy centralnej w latach 1981-1985. Jego autorka, Danuta Koźmian prezentuje dzieje Szczecina jako ośrodka akademickiego i życia naukowego i jednocześnie wykazuje, jak wielkie znaczenie dla miasta i regionu mialo powolanie uniwersytetu.

Joanna Schiller natomiast przenosi czytelników w wiek XIX i przedstawia problemy katedry literatury polskiej w Cesarskim Uniwersytecie Warszawskim. Problemy te są na tyle interesujace, bo pamiętać należy, iż wymieniona uczelnia powstała nie po to by mlodych Polaków kształcić, ile ich rusyfikować i wynaradawiać. Stąd i finał rozmyślań J. Schiller jest oczywisty: pomysł powołania katedry literatury polskiej pozostał w sferze projektów, a wykład z tego przedmiotu prowadzony był.... po rosyjsku.

Władysława Szulakiewicz prezentuje artykuł na temat: Pokolenie lwowskich historyków oświaty $i$ wychowania (Szkic tematu badawczego). Obszarem zainteresowań autorki był lwowski ośrodek naukowy, a szczególnie osoba Stanisława Łempickiego i grono jego uczniów. Ich wkład, zdaniem autorki, w rozwój polskiej historii wychowania, szczególnie w II połowie XX wieku był znaczacy, $w$ zakresie dorobku naukowego, jak tez $w$ dziedzinie organizacyjno-naukowej ${ }^{5}$.

Ciekawych informacji dostarcza kolejny współautor tomu - Ryszard Terlecki. Przedstawia on bowiem działania operacyjne Wydziału II krakowskiej Słuźby Bezpieczeństwa podczas jubileuszu 600-lecia Uniwersytetu Jagiellońskiego. I chociaż autor ten stwierdza, iż ta wielka operacja SB zakończyła się pomyślnie, o czym świadcza materiały i dokumenty, to dopiero pełne rozpoznanie archiwów UB i SB umożliwi napisanie na nowo dziejów UJ w czasach władzy komunistycznej.

Ostatnim artykułem $w$ tej części pracy jest Tożsamość polskiego Uniwersytetu Wrocławskiego, autorstwa Wojciecha Wrzesińskiego. Autor ten wykazuje jak na przestrzeni kilkudziesięciu lat ta tożsamość ulegała przemianom, zawsze zależna od polityki i układów. Postuluje także, aby czynniki te nie naruszały wolności badań naukowych $\mathrm{i}$ ich głównej normy: poszukiwania prawdy. Bo powodzenie tych dazeń decyduje o przyszlości Uniwersytetu, modernizacji, zachowania tozsamości ideowej i programowej, przy wolności stowa $i$ myśli, poczuciu wspótodpowiedzialności za przyszlość wychowania nowych pokolen, jutro narodu $i$ państwa 6 .

Druga część pracy poświęcona jest stanowi nauczycielskiemu. Otwiera ją Józef Barański swoim artykułem pt.: Ksztatcenie nauczycieli $w$ Ciechanowie $w$ latach 1946-1995. Wykazuje on, jak wielkie znaczenie miał ten ośrodek dla uzupełniania braków kadrowych całego regionu.

Do przełomu XVIII i XIX wieku cofają nas rozważania Katarzyny Buczek. Przedstawia ona 
bowiem artykuł traktujący o problemach zawodu nauczycielskiego w ujęciu Hugona Kołłątaja. Rozważania te są interesujące, ponieważ dla tego zasłużonego dla polskiej oświaty działacza rola nauczycieli nie ograniczała się jedynie do zagadnień teoretycznych, ale $w$ rozwoju profesji tej widział on szanse na rozwój i pomyślność Rzeczypospolitej.

Janina Chodakowska snuje rozważania na temat seminariów w uniwersytetach galicyjskich na przełomie XIX i XX wieku. Autorka ta przedstawia, jaki był cel powstawania seminariów, kto o tym decydował, jaki byl ich zakres działań, z jakimi problemami musiały się one borykać.

Kolejny artykuł nosi tytul: Seminarium Nauczycielskie w Poznaniu w 1808 roku wedtug „Doniesienia powszechności o urzadzeniu Seminarji Uczycielskiej Poznańskiej" Józefa Jeziorowskiego i kwestia jego genezy. Jego autor to Adam Fijałkowski, biograf Jeziorowskiego, którego postać wiązana jest $\mathrm{z}$ powołaniem do życia seminarium nauczycielskiego w Poznaniu. Uzupełnieniem pracy A. Fijakowskiego jest dołaczony do tekstu zasadniczego dokument, o którym jest mowa w tytule.

Rozważania Ludwika Grzebienia, kolejnego autora, dotycza nauczycieli świeckich w szkołach jezuickich w Polsce od XVI do XVIII wieku. Wprowadzaja one nowe watki w studiach poświęcanych Towarzystwu Jezusowemu, a mianowicie: w szkołach jezuickich do 1773 roku uczyli nie tylko zakonnicy, ale również nauczyciele świeccy, a także to, że jezuici nie poświęcali się wyłącznie szkolnictwu średniemu i wyższemu - prowadzili bowiem także szkółki parafialne.

Gdy mowa o stanie nauczycielskim nie mogło zabraknać przedstawienia choćby jednej sylwetki pedagoga. Zadanie to wykonał Tadeusz Jalmużna, pisząc i przybliżając czytelnikom postać Julii Kisielewskiej, plockiej nauczycielki i działaczki, zwolenniczki metod "nowego wychowania", pisarki.

Portret zbiorowy nauczycieli kreśli Adam Massalski w swojej pracy: Nauczyciele prawa szkót średnich rzadowych $w$ Królestwie Polskim $w$ latach 1833-1862. Autor ten zwrócił uwagę na to, że choć grupa tych nauczycieli nie była liczna, to miała ona swój udział we wszystkich zrywach niepodległościowych i działalności o charakterze wolnościowym.
Irena Szybiak przedstawia Krystyna Lacha Szyrmy rozwazania o stanie nauczycielskim $w 1830$ r., na pierwszym w Polsce odnowieniu doktoratu. Bohaterem tej uroczystości był Michał Kubeszowski, jeden z ostatnich wówczas świadków i uczestników reformy Komisji Edukacji Narodowej, kształcony w już zreformowanej Akademii Krakowskiej. Sam Szyrma zaś był chłopskim synem, robiącym karierę naukową i polityczną.

Część dotycząca problematyki nauczycielskiej zamyka artykuł Ryszarda W. Wołoszyńskiego na temat postaw nauczycieli Wileńskiego Okręgu naukowego 1802 - 1831, ich roli i udziału w działaniach powstańczych 1831 roku.

Kolejnych dziesięć publikacji pos̉więconych jest szkołom i nauczaniu. Pierwsza z nich, autorstwa Marka Inglota, traktuje o Kongregacjach (Sodalicjach) Mariańskich w szkołach jezuickich od XVI do XVIII wieku i ma charakter postulatu badawczego.

Watek religijny kontynuuje Hanna Konopka w artykule: Przeciw modlitwom $w$ szkotach. Wprowadzenie apeli porannych w 1954 roku. Autorka ta stwierdza, że akcja powszechnego wprowadzania apeli porannych w szkołach, zaniechanie modlitw przed i po lekcjach, usunięcie nauki religii ze wszystkich szkół zawodowych i większości liceów ogólnokształcących była dla oficjalnych władz sprawdzianem przed ostatecznym wyrzuceniem Kościoła ze szkól, a nawet przed planowana wojna $\mathrm{z}$ katolicyzmem. Temu zaś służyć miała akcja usuwania krzyży i innych symboli religijnych ze szkót. To jednak temat na osobny artykuł...

Stanisław Litak przedstawia z kolei kryzys szkolnictwa parafialnego w Rzeczypospolitej i pierwsze próby jego odbudowy przed powstaniem KEN. Badacz ten upatruje przyczyny tego stanu rzeczy przede wszystkim w kryzysie gospodarczym i politycznym, zniszczeniach wojennych, kostnieniu wyznań protestanckich i zbyt powolnych reformach podjętych przez Kościól.

W czasy peerelowskie wprowadza czytelnika Antykomunistyczna konspiracja mtodziezy szkolnej 1945-1956, autorstwa Stanisława Mauersberga. Zjawisko to prezentuje on jako niezwykłe zjawisko, a jednocześnie pokazuje dramat młodego pokolenia, które w żaden inny sposób nie potrafiło lub nie chciało sprzeciwić się smutnej, komunistycznej rzeczywistości. 
Andrzej Meissner natomiast bada zjawisko kształtowania się dydaktyki szkoły ludowej w Galicji doby autonomicznej. Wskazuje specyfikę zaboru austriackiego, a także ewolucję, jaka przeszła tam szkola elementarna (od herbartyzmu przez pestaloccyzm do progresywizmu) i jak wielki wpływ na nią mieli galicyjscy pedagodzy: Mieczysław Baranowski, Henryk Rowid, Marian Falski, Eugeniusz Piasecki czy Barbara Żulińska.

Problematykę polskiego szkolnictwa $\mathrm{z}$ dobie zaborów kontynuuje Bożenna Michalik. Jej praca dotyczy bowiem szkolnictwa warszawskich ewangelików w walce $z$ rusyfikacja. Badaczka ta pokazuje całe bogactwo działań tego środowiska $\mathrm{w}$ walce $\mathrm{z}$ wynaradawianiem, działań nie polegajacych tylko i wyłacznie na oporze w szkole, ale także poprzez np. zakładanie i utrzymywanie ochronek.

Kolejna część pracy to artykuł Lecha Mokrzeckiego, przedstawiajacy dzieje Polskiego Konserwatorium Muzycznego w Gdańsku. Powstałe w okresie międzywojennym, stanowić ono miało przeciwwage dla tego typu placówek niemieckich (w liczbie czterech).

Krakowski historyk wychowania, Zygmunt Ruta, wprowadza czytelnika $w$ lata trzydzieste $\mathrm{XX}$ wieku. Jego praca dotyczy szkolnictwa powszechnego w Okręgu Szkolnym Lwowskim. Natomiast Janusz Szczepański pisze o nastrojach i działaniach polskiej młodzieży szkolnej wobec najazdu bolszewickiego w 1920 roku. Autor ten zaznacza szczególne zaangażowanie polskich harcerzy, których organizacja na ziemiach polskich liczyła sobie niecałe dziesięć lat...

Charakter pracy regionalnej ma publikacja Teresy Zaniewskiej. W kręgu jej zainteresowań znalazło się gimnazjum w Sterdyni w latach 1942-1950. Artykuł ten powstał jako ,pomnik" dla utrwalenia idei placówki i ludzi ją tworzacych w wyjatkowo nieprzychylnych czasach.

Ostatnia, czwarta część pracy poświęconej Prof. Józefowi Miąso nosi tytuł: Edukacja a spoteczeństwo. Otwiera ja Tadeusz Bieńkowski, piszący o refleksach pedagogiki renesansowej w twórczości Jana Kochanowskiego. Autor ten wykazuje, że Kochanowskiego bardzo interesowała problematyka człowieka, jego losu, możliwości działania $\mathrm{i}$ celu życia $\mathrm{i}$ widzi $\mathrm{w}$ tym wplyw Erazma z Rotterdamu, a także wielu podróży, które Kochanowski odbył.
Katarzyna Dormus natomiast przybliża sylwetkę Marii Turzymy-Wiśniewskiej, jednej z najaktywniejszych działaczek radykalnego odłamu polskiego ruchu kobiecego, znanej publicystki, redaktorki feministycznego „Nowego Słowa”, autorki nowel i dramatów, postaci ciaggle mało znanej i docenianej.

Kolejny artykuł nosi tytut: Modele rodziny jako środowiska wychowawczego wypracowane $i$ upowszechniane $w$ polskim piśmiennictwie pedagogicznym $i$ rodzinnym drugiej polowy XIX i poczatków XX wieku. Jego autorem jest Krzysztof Jakubiak. Artykuł ten wydatnie wzbogaca dorobek polskich historyków wychowania na temat rodziny, tematyki, jak sam autor podkreśla, obecnej w refleksji naukowej dopiero od lat siedemdziesiatych ubiegłego stulecia.

Rozważania Wieslawa Jamrożka dotyczą Ignacego Solarza i jego koncepcji wiejskiego uniwersytetu ludowego. W zamyśle autora koncepcji miał to być zakład wychowawczy o charakterze ogólnoksztatcacym, przeznaczony dla miodzieży w wieku poszkolnym, [gdzie - E. G. S.] nie chodzito jednak o zaznajamianie wychowanków $z$ podstawami usystematyzowanej wiedzy, ale przede wszystkim o ksztaltowanie światopogladu, przygotowanie do uczestnictwa $w$ spoteczno-kulturalnym zyciu wsi i narodu? ${ }^{7}$.

Wyksztalceniem w Rzymie cesarskim zajmuje się Juliusz Jundziłł. Według tego autora najlepszym okresem dla zdobywania wyksztalcenia były czasy od II do początków IV wieku $n$. e. I nie był to wynik świadomej polityki państwa, ale obiektywnej sytuacji: poziomu rozwoju społecznego, stopnia uspołecznienia funkcjonowania państwa. W tamtych czasach, na co zwrócil uwage J. Jundzilt, studiowano retorykę, filozofię czy też literaturę nie dla zysku, ale dla wlasnej przyjemności i giętkości umystu.

Jerzy Maternicki analizuje polskie badania nad dziejami edukacji historycznej lat 1991 -2002. Wynik tej refleksji jest zadowalajacy: Polacy maja spory dorobek $w$ tej dziedzinie, badania ich prowadzone sa coraz intensywniej i przywiązuja one wage do np. mentalności ludzi, czyli nawiazuja one do obecnego już od dawna w europejskiej myśli historycznej nurtu szkoły Annales.

Watki edukacyjne w życiu i działalności Marii Skłodowskiej-Curie bada Jan Piskurewicz. 
Stawia ten badacz przed sobą zadanie pokazania słynnej polskiej noblistki jako uczennicy, studentki, nauczycielki i profesora uniwersytetu.

Karol Poznański przedstawia natomiast kulisy i skutki ustanowienia Warszawskiego Okręgu Naukowego w 1839 roku. Powołanie tej instytucji było prawdopodobnie pomysłem cara i bez watpienia byt to zamyst wywotania nowej fali swoistej agresji wobec rdzennie polskiej tradycji oświatowej ${ }^{8}$.

Przedstawieniem zobowiazań oświatowych polskich królow elekcyjnych w świetle pactarum conventorum zajał się Jan Ryś. Owe zobowiązania dotyczyły przede wszystkim potwierdzenia praw i przywilejów Akademii Krakowskiej, a także powołania do życia szkoły wojskowej dla niezamożnej szlachty. Ten ostatni zamysł zrealizowal dopiero Stanisław August... Mimo to jego Szkoła Rycerska i jej wychowankowie zapisali piękną kartę w dziejach polskiej oświaty.

Kolejny artykuł to Rola edukacyjna kancelarii królewskiej w Rzeczypospolitej (1576 -1632) (z problematyki wyksztatcenia elity urzędniczej w czasach nowozytnych) Wojciecha Sokolowskiego. Powstał on, ponieważ, jak zauważyl sam autor, brakuje prac, kıóre ukazywatyby „portret zbiorowy" sekretariatu monarszego z uwzględnieniem ich roli, rangi, funkcji $i$ wyksztatcenia 9 . Artykuł prezentowany z powodzeniem owa lukę wypełnia.

Bliska Poznaniakom będzie z pewnością kolejna pozycja - rys biograficzny Antoniego Danysza, wielkopolskiego pedagoga, orędownika kierunku herbartowskiego w polskiej pedagogice przełomu wieku, kierownika i twórcy Katedry Pedagogii w Uniwersytecie Poznańskim. Autorem tego rysu biograficznego jest Andrzej Śródka.

Zwiazki Floriana Znanieckiego z pedagogika odkrywa Wiesław Theiss. Przedstawia tego pol- skiego socjologa jako uczestnika trzech konferencji: Pracowników Oświatowych RP w Kazimierzu n/Wisła, Międzynarodowego Kongresu Ligi Nowego Wychowania w Helsingor i Międzynarodowego Kongresu Wychowania Moralnego w Krakowie.

Leszek Zasztowt natomiast bada i przedstawia liczbę drobnej szlachty w zachodnich guberniach Cesarstwa Rosyjskiego, zdegradowaną do stanów włościańskiego i mieszczańskiego w latach 1831 - 1868. Publikacja ta jest odpowiedzią na prace Daniela Beauvois, Polacy na Ukrainie 1831-1863. Szlachta polska na Wotyniu, Podolu i Kijowszczyźnie (Paryż 1987), która rozpoczęła dyskusję na ten temat.

Cały tom zamyka wspomnienie o Annic z Firlejów Ossolińskiej, autorstwa Doroty Żolądź-Strzelczyk, historyczki wychowania epoki staropolskiej. W jej oczach Anna to troskliwa i zapobiegliwa matka, nie tylko dla własnych dzieci, ale i pasierbów. I choć żyła krótko warto o niej pamiętać, jak o wzorcu osobowym swojej epoki.

Sądzę, iż wszyscy autorzy zbioru bliscy sa intencjom D. Żołądź-Strzelczyk i swoją praca chcieli utrwalić jako wzór Mistrza, Profesora i Nauczyciela osobę Józefa Miasso. Tym samym zrobili Mu prezent na 75-te urodziny, które wypadaja w tym roku.

\section{Edyta Glowacka-Sobiech}
1 S. 16.
2 S. 22.
3 S. 64.
4 Ibidem.
5 S. 147.
6 S. 184.
7 S. 428.
8 S. 470 .
9 S. 494.

\section{Edmund Juśko, Szkolnictwo powszechne w powiecie tarnowskim w latach 1918-1939, Towarzystwo Naukowe Katolickiego Uniwersytetu Lubelskiego, Lublin 2003, ss. 405}

Wydana przez Wydawnictwo Naukowe Katolickiego Uniwersytetu Lubelskiego pozycja jest poszerzona wersja rozprawy doktorskiej obronio- nej w KUL. Autor prezentowanej książki, po ukoniczeniu studiów historycznych $w$ tej uczelni, przez kilka lat pracował jako nauczyciel historii 